\title{
Chinese Customers' Sensory Evaluation between Chinese Wine and Foreign Wine
}

\author{
Xiang LI \\ International College \\ Beijing University of Agriculture \\ Beijing, China \\ Xinyue ZHU \\ International College \\ Beijing University of Agriculture \\ Beijing, China \\ Siyao WANG \\ International College \\ Beijing University of Agriculture \\ Beijing, China
}

\author{
Yujun LIU \\ International College \\ Beijing University of Agriculture \\ Beijing, China \\ Keith Walley \\ Business Management \& Marketing Department \\ Harper Adams University \\ Newport, United Kingdom
}

\author{
Yukun LI * \\ International College \\ Beijing University of Agriculture \\ Beijing, China \\ *Corresponding author
}

\begin{abstract}
Except for the Wine's brands, price, promotion, Customers have different sensory evaluation towards to the Chinese Wine and Foreign wine, which can affect the customers' purchasing decisions. The survey about the consumer's preferences toward the Chinese Wine and foreign wine is implemented. Especially, the important level and customer's satisfaction level about the colour, aroma and taste of wine are analyzed with the customers' preference.
\end{abstract}

Keywords-Chinese wine; foreign wine; Chinese consumers; Color-aroma; taste

\section{INTRODUCTION}

\section{A. The wine market in China}

According to the studies of the archaeology, the wine has a history of 6000 years $^{[1]}$. The wine industry has developed in China from 1978 to 1992.The wine total annual output for that period has reached more than 50 thousand tons, however, varieties, packaging, technology and other relatively backward ${ }^{2}{ }^{2}$. In 1994 with the propaganda of the media, the red wine was in great demand and it caused the shortage of red wine, so the foreign wine traders are poured in China $\left.{ }^{[3}\right]$. From 2002 to now, the annual output of wine increased at an annual rate of $15 \%-20 \%$. The data show that in 2016, from January to September, the domestic wine productions achieved 81.10 liters and the imported wine quantity reached 48.49 liters, the annual production of imported wines and domestic wines has increased year by year.

\section{B. Wine features of countries}

The wines from different countries have different characteristics. France is famous for producing countless high-end wines and its variety of tastes varies greatly, thus, it has been honored as "grape kingdom"[ $\left.{ }^{4}\right]$. Italy wine is characterized by its strong taste and acidity, which is more suitable for Chinese food. Australian wines are characterized by its chocolate and fruit aromas. Spain is dominated by red wine and it also has outstanding white wine and sparkling CAVA. Chinese wine prices are relatively low, to meet the needs of some groups.

\section{The choice of Chinese consumer}

On the basis of a survey, most Chinese consumers like domestic wine and they usually choose medium and low-end wines ${ }^{[5]}$. Analyzing from the view wine's price, $60 \%$ Chinese consumers prefer to choose the wine around 100-500 Yuan. From the survey, it showed that when consumers made a decision to purchase wine, they concerned with the wine's taste, price, brand, quality, and the cost performance ${ }^{[6]}$.

\section{Methodology}

At the aim of explore the Chinese customers' sensory evaluation in the purchasing process between Chinese Wine and Foreign wine. According to our statistics, 452 questionnaires are distributed and 400 are valid. Using cross tabulation and chi-square test to analyze the above data in the SPSS software.

\section{RESUltS ANALYSIS}

\section{A. Consumption related information}

The table I is the consumption related information of this survey. As can be seen from the table, most of the respondents often drink wine but rarely buy their own a year. This shows that most of the wine drinkers take wine from others presented. From the data of desire for wine can also be seen in the side of 
this phenomenon, most of the respondents like to drink wine, but do not want to buy. Nearly half of the respondents chose to buy wine of 100-299 yuan, which is a middle and low price. This phenomenon may be caused by most of the consumers knowledge of the wine is only partially, and they worried that they cannot identify which is good wine. Therefore, they choose their own acceptable price, to avoid the risk of choosing high-priced wine.

TABLE I. CONSUMPTION RELATED INFORMATION

\begin{tabular}{|c|c|c|c|}
\hline \multicolumn{2}{|c|}{ Desire for wine } & \multicolumn{2}{|c|}{ Price level(Yuan) } \\
\hline \multicolumn{2}{|c|}{ Dislike, null buy $\quad 18.80 \%$} & \multirow{2}{*}{\multicolumn{2}{|c|}{$\begin{array}{lr}\text { Less than } 100 & 24.60 \% \\
100-299 & 45.4 \%\end{array}$}} \\
\hline Like, null buy & $34.70 \%$ & & \\
\hline Dislike, want-buy & $21.50 \%$ & 300-599 & $23.5 \%$ \\
\hline \multirow{2}{*}{ Like, want-buy } & $24.30 \%$ & 600-999 & $5.1 \%$ \\
\hline & & \multicolumn{2}{|c|}{ knowledge about wine } \\
\hline \multirow{2}{*}{\multicolumn{2}{|c|}{$\begin{array}{l}\text { How long drink wine } \\
\text { More than once/week 22.8\% }\end{array}$}} & know wine wel & $1.1 \%$ \\
\hline & & Just know & $23.2 \%$ \\
\hline Unce 2 weeks & $22.3 \%$ & Partly know & $39.6 \%$ \\
\hline Over monthly & $10.2 \%$ & know a little & $26.8 \%$ \\
\hline & & don't know & $9.3 \%$ \\
\hline \multirow{2}{*}{\multicolumn{2}{|c|}{ Bottles per year }} & \multicolumn{2}{|c|}{ Concerns when purchasing } \\
\hline & & Too expensive & $29.4 \%$ \\
\hline Less than 6 bottles & $45.1 \%$ & Cannot identify & $31.2 \%$ \\
\hline 7-12 bottles & $28.3 \%$ & Inconvenient & $10.4 \%$ \\
\hline 13-24 bottles & $18.6 \%$ & Unaccustomed ta & ste $18.1 \%$ \\
\hline 25--48 bottles & $5.1 \%$ & $\begin{array}{r}\text { Low performan } \\
\text { ratio10.8 }\end{array}$ & $\begin{array}{l}\text { ce price } \\
\%\end{array}$ \\
\hline
\end{tabular}

B. Color-aroma influence the customers purchase choice

For a better explanation to the factors that affect consumer decision to choose the Chinese wine or the foreign wine, the cross tabulation and Chi - square test (TABLE II) were applied for analysis the relationship between importance and satisfaction level by SPSS. The survey shows color-aroma is quite important, not only because the color brings the visual impact, but also due to consumers always do not have the opportunity to taste wine before they buy it.

TABLE II. CROSS TABULATION AND CHI-SQUARE TEST FOR “CONSUMERS CHOOSE CHINESE WINE OR FOREIGN WINE” AND “THE IMPORTANT LEVEL OF THE COLOUR-AROMA OF WINES”

\begin{tabular}{|l|l|l|l|l|l|l|}
\hline & Level 1 & Level 2 & Level 3 & Level 4 & Level 5 & Total \\
\hline Chinese wine \% & $0.5 \%$ & $4.5 \%$ & $31.2 \%$ & $42.1 \%$ & $21.8 \%$ & $100.0 \%$ \\
\hline Foreign wine \% & $3.7 \%$ & $2.4 \%$ & $18.3 \%$ & $40.2 \%$ & $35.4 \%$ & $100.0 \%$ \\
\hline total\% & $2.2 \%$ & $3.3 \%$ & $24.2 \%$ & $40.9 \%$ & $29.4 \%$ & $100.0 \%$ \\
\hline & Value & df & Asymp. Sig. (2-sided) \\
\hline Pearson Chi-Square & $93.649^{\mathrm{a}}$ & 8 & .000 & \\
\hline
\end{tabular}

a 5cells(33.3\%)have expected count less than 5 . The minimum expected count is 0.02

Color-aroma's important degree is divided into 5 extents in TABLE II, from very important (level 5) to very unimportant (level 1). According to questionnaire, $21.8 \%$ of Consumers Who Selected the Chinese wine (CSC) considered colour-aroma is very important, where Consumer Who Selected Foreign Wine (CSF) occupied 35.4\%, meanwhile CSF (3.7\%) takes up 7 times than CSC $(0.5 \%)$ in very unimportant. From very important and very unimportant, data indicates that CSF has a stronger personal opinion, higher expectations of wine and richer expected factors than CSC. The Chi-square test indicates that the color-aroma can significantly affect the consumer purchase.

\section{Taste influences the customers Purchase choice}

Except for color-aroma, taste is also a vital factor that affects purchase. According to the TABLE III, it can be seen that from the viewpoint of consumers, the importance of foreign wine taste was significantly greater than the Chinese wine, respectively, $41.1 \%$ and $26.2 \%$. Instead, the most significant data of CSC is no attitude (level 3), which is $41.6 \%$, indicating most of CSC have no strong personal opinion to Chinese wine. However, whether prefers the foreign wine consumers or Chinese wine consumers, few consumers (both below 5\%) completely neglect the taste of wines. So, comparing with the Chinese wine, the customers who prefer to the foreign wine are more value the taste. Chi-square test suggests that the importance of taste has strong relativity with the customer prefer domestic wine or imported wine to explore how taste influences the customers' purchase figure (Fig. 1) is made to illustrate consumers' consideration towards Chinese wine and Foreign wine.

TABLE III. CROSS TABULATION AND CHI-SQUARE TEST FOR "CONSUMERS USUALLY CHOOSE CHINESE WINE OR FOREIGN WINE" AND “THE IMPORTANT LEVEL OF THE TASTE OF WINES”

\begin{tabular}{|c|c|c|c|c|c|c|}
\hline & Level 1 & Level 2 & Level 3 & Level 4 & Level 5 & Total \\
\hline Chinese wine \% & $0.5 \%$ & $3.0 \%$ & $41.6 \%$ & $28.7 \%$ & $26.2 \%$ & $100.0 \%$ \\
\hline Foreign wine \% & $1.2 \%$ & $3.6 \%$ & $21.4 \%$ & $32.7 \%$ & $41.1 \%$ & $100.0 \%$ \\
\hline Total\% & $0.9 \%$ & $3.3 \%$ & $30.3 \%$ & $31.0 \%$ & $34.5 \%$ & $100.0 \%$ \\
\hline \multicolumn{3}{|c|}{} & Value & df & \multicolumn{3}{c|}{ Asymp. Sig. (2-sided) } \\
\hline \multicolumn{2}{|c|}{ Pearson Chi-Square } & $24.575^{\mathrm{a}}$ & 8 & \multicolumn{5}{c|}{.002} \\
\hline
\end{tabular}

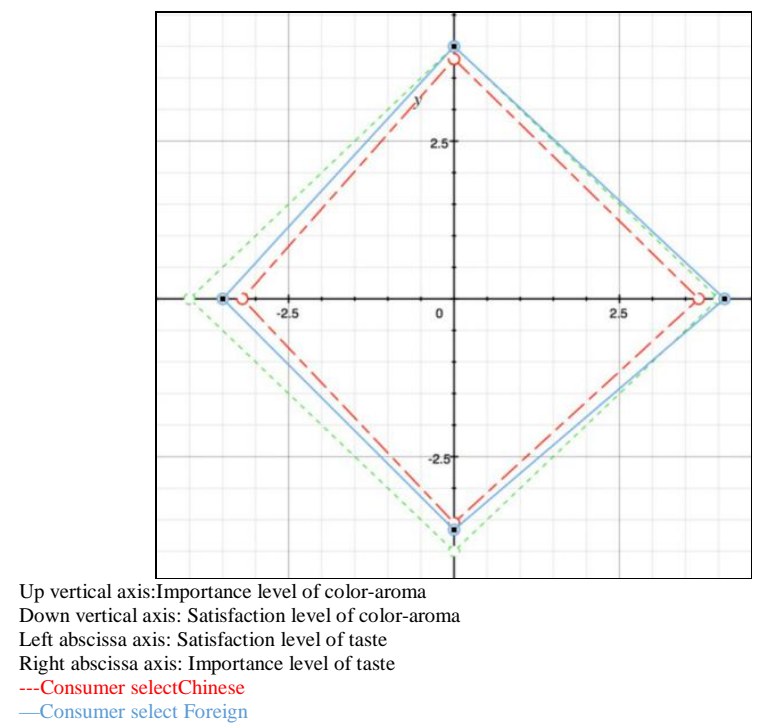

Fig. 1. The mean of taste and color-aroma of wines

Fig. 1 set value 4 as the vertex to compare Chinese wine (red) and Foreign wine (blue), it illustrates that foreign wine always take more weight (approximately 0.2) than Chinese wine which means consumer always require more characters on foreign wine than Chinese wine. However, the taste factor of CSF on horizontal line, consumer gives 4.089 to important but only give 3.472 to satisfaction, derive that consumers are 
not that satisfy the taste of their choice, so the merchant can do more effort on the taste of foreign wine. Chi-square test in TABLE IV shows strong relativity between taste satisfaction level and choose Chinese/Foreign wine.

TABLE IV. CHI-SQUARE TEST FOR “CONSUMERS USUALLY CHOOSE CHINESE WINE OR FOREIGN WINE”

\begin{tabular}{|c|c|c|c|}
\hline & $\begin{array}{c}\text { Importance/satisfact } \\
\text { ion level to } \\
\text { color-aroma }\end{array}$ & $\begin{array}{c}\text { Importance/satisfact } \\
\text { ion level to taste }\end{array}$ \\
\hline $\begin{array}{c}\text { Willing to } \\
\text { buy } \\
\text { Chinese/forei } \\
\text { gn wine }\end{array}$ & $\begin{array}{c}\text { Pearson } \\
\text { correlati } \\
\text { on }\end{array}$ & $0.000 / 0.075$ & $0.000 / 0.011$ \\
\hline
\end{tabular}

\section{Consumer characteristics impact on buying HRW}

Chinese customers' performance towards Chinese wine or foreign wine and their sensory evaluations about wine are influenced by some factors, such as education, income, country of origin, price, and purchase frequency. In order to explore their relationships, the results of the Pearson correlation test are showed in the TABLE V. Initially, from the result table we can find that the customers willing to buy Chinese wine or foreign wine is significantly impacted by their education level, purchase frequency and the price of wines. What needs illustrating is that high-education level consumers prefer to purchase foreign wine than Chinese wine. Besides, foreign wine is described as premium wine in the most consumers mind. Secondly, what can be saw clearly that all the factors (consumers'education level, income, purchase frequency and wine's country of origin and price) have a significant influence in the important and satisfactory level to wine' colour-aroma of consumers. Wine's colour and aroma are a pre-purchase search of consumers, which determines whether they willing to purchase the wine and it is influenced by the consumers' inner factors and external factors. Thirdly, different from the colour-aroma, importance and satisfaction level to taste only has a significant correlation with the country of origin and the importance level of taste also has can be significantly affected by consumers purchase frequency. It should be pointed out that consumers taste evaluation is a post-purchase behavior, and the better taste evaluation lead to more frequently purchasing behavior. In addition, wines' origin country impacts consumers drinking experience.
TABLE V. THE RESUlts of PEARSON CORRELATION TEST

\begin{tabular}{|c|c|c|c|c|}
\hline & \multicolumn{2}{|c|}{$\begin{array}{c}\text { Willing to buy } \\
\text { Chinese or foreign } \\
\text { wine }\end{array}$} & $\begin{array}{c}\text { Importance/satis } \\
\text { faction level to } \\
\text { colour-aroma }\end{array}$ & $\begin{array}{c}\text { Importance } \\
\text { /satisfactio } \\
\text { n level to } \\
\text { taste }\end{array}$ \\
\hline Education & $\begin{array}{c}\text { Pearson } \\
\text { correlation }\end{array}$ & $\begin{array}{c}0.00 \\
1\end{array}$ & $0.001 / 0.000$ & $0.292 / 0.393$ \\
\hline Income & $\begin{array}{c}\text { Pearson } \\
\text { correlation }\end{array}$ & $\begin{array}{c}0.09 \\
4\end{array}$ & $0.000 / 0.000$ & $0.167 / 0.059$ \\
\hline $\begin{array}{c}\text { Country of } \\
\text { origin }\end{array}$ & $\begin{array}{c}\text { Pearson } \\
\text { correlation }\end{array}$ & $\begin{array}{c}0.02 \\
7\end{array}$ & $0.000 / 0.000$ & $0.000 / 0.001$ \\
\hline Price & $\begin{array}{c}\text { Pearson } \\
\text { correlation }\end{array}$ & $\begin{array}{c}0.00 \\
0\end{array}$ & $0.000 / 0.000$ & $0.063 / 0.266$ \\
\hline $\begin{array}{c}\text { Purchase } \\
\text { frequency }\end{array}$ & $\begin{array}{c}\text { Pearson } \\
\text { correlation }\end{array}$ & $\begin{array}{c}0.04 \\
5\end{array}$ & $0.000 / 0.112$ & $0.016 / 0.362$ \\
\hline
\end{tabular}

\section{CONCLUSION}

Most consumers in China generally have three purposes to purchase wine: for collect, for beauty and for status. Colour-aroma and taste were illustrating effect consumer deeply. Consumers who select the Chinese wine spend less concern on colour and aroma meanwhile shows lower satisfaction and expectation. Consumers who select foreign wines consider colour-aroma are more important than Chinese wine and show higher satisfaction. For the taste factor, the customers who prefer to the foreign wine treasure the taste, has higher satisfaction than who prefer Chinese wine. Almost all foreign wine-preferred consumers consider taste is a vital factor

\section{ACKNOWLEDGMENT}

Beijing University of Agriculture and Harper Adams University UK gave us support to finish the article. It was appreciated that our teacher Yukun Li, aiding us with the data analysis and instructing us have a better research in this topic.

\section{REFERENCES}

[1] Lei, Y. and Wei, Z. A preliminary study on the history and culture of wine in China. Mass literary magazine, (2016) 263-264.

[2] Yueru, Z. The Study of Foreign Grape Wine' Marketing Strategy in Chinese Market. Tianjin University, (2012) 1-3.

[3] Jiagui, L. The consumer behavior of wine in China. Northwest A\&F University, (2014) 63-67.

[4] Persson, I.Red wine, white wine, rosé wine, and grape juice inhibit angiotensin-converting enzyme in human endothelial cells. International journal of Nutrition, Pharmacology, Neurological Diseases, (2013) 17-23.

[5] Yanghua, L. Consumer behavior analysis of Chinese red wine market. Theoretical Research, (2013) 217-218.

[6] URL:http://www.chinanews.com/wine/2013/04-22/4752118.shtml (15.3. 2017.) 